\title{
Efektivitas Konseling Behavioral Dengan Teknik Modeling Untuk Meningkatkan Self Succorance Melalui Lesson Study Siswa Kelas VIII.4 Smp Negeri 2 Singaraja
}

\author{
Efektivitas Konseling Behavioral Dengan Teknik Modeling Untuk Meningkatkan Self Succorance \\ Melalui Lesson Study Siswa Kelas VIII.4 Smp Negeri 2 Singaraja
}

\author{
I Komang Ribek Teja Budiarta ${ }^{1}$, I Ketut Dharsana ${ }^{2}$, Ni Ketut Suarni ${ }^{3}$ \\ Universitas Pendidikan Ganesha \\ Gmail: teja96budiarta@gmail.com
}

Received Month DD, 20YY; Revised Month DD, 20YY; Accepted Month DD, 20yy; Published Online DD, 20yy

\section{Conflict of Interest Disclosures: \\ The authors declare that they have no significant competing financial, professional or personal interests that might have influenced the performance or presentation of the work described in this manuscript.}

\begin{abstract}
This study aims to determine the effectiveness of behavioral counseling with modeling techniques to improve self-assessment through lesson study of class VIII.4 Singaraja 2 Public Middle School. Experimental research using the pretest-postest Control Group Design. The population of this research is the eighth grade students of Singaraja 2 Public Middle School. The study sample was 60 students. Through random sampling techniques, 30 students were placed in the experimental group class VIII.4 and 30 students were in the control group class VIII.9. The research data was analyzed by independent sample t-test using JASP version 0.10.0.0 and d'Cohen software applications to determine the level of effectiveness. The results obtained $t=14,921, p<0.05$, Examiners Effect Size (ES) showed high effectiveness $=($ ES 3.853), These results proved behavioral counseling with effective modeling techniques to improve self-assessment of class VIII.4 students of SMP Negeri 2 Singaraja. For this reason, BK counselors can use behavioral counseling with modeling techniques to improve self-assessment in class VIII Singaraja 2 Public Middle School.
\end{abstract}

Keywords: Behavioral counseling, modeling techniques,self succorance, lesson study

Abstrak. Penelitian ini bertujuan untuk mengetahui keefektifan konseling behavioral dengan teknik modeling untuk meningkatkan self succorance melalui lesson study siswa kelas VIII.4 SMP Negeri 2 Singaraja. Penelitian eksperimen menggunakan pretest-postest Control Group Desain. Populasi penelitian ini siswa-siswa kelas VIII SMP Negeri 2 Singaraja. Sampel penelitian ini 60 siswa. Melalui teknik random sampling, 30 siswa ditempatkan kelompok eksperimen kelas VIII.4 dan 30 siswa merupakan kelompok kontrol kelas VIII.9. Data penelitian ini dianalisis dengan independent sampel t-test menggunakan aplikasi software JASP version 0.10.0.0 dan d'Cohen untuk mengetahui tingkat keefektifan. Hasil penelitian mendapatkan $\mathrm{t}=14.921, \mathrm{p}<0,05$, Penguji Effect Size (ES) menunjukkan keefektifan yang tinggi $=($ ES 3.853), Hasil tersebut membuktikan konseling behavioral dengan teknik modeling efektif untuk meningkatkan self succorance siswa kelas VIII.4 SMP Negeri 2 Singaraja. Untuk itu kepada guru 
BK dapat menggunakan konseling behavioral dengan teknik modeling untuk meningkatkan self succorance pada siswa kelas VIII SMP Negeri 2 Singaraja.

Kata-kata kunci: Konseling behavioral, teknik modeling, self succorance, lesson study.

How to Cite: I Komang Ribek Teja Budiarta, I Ketut Dharsana, Ni Ketut Suarni. (2019). Efektivitas Konseling Behavioral Dengan Teknik Modeling Untuk Meningkatkan Self Succorance Melalui Lesson Study Siswa Kelas VIII.4 Smp Negeri 2 Singaraja. Konselor, VV (N): pp. 64-69, DOI: 10.24036/XXXXXXXXXX-X

\section{Pendahuluan}

Berdasarkan hasil pengamatan penelitian dari 30 siswa peneliti melihat 14 siswa menunjukan gejala-gejala seperti menunjukkan sikap seperti siswa terlihat sangat tidak memperhatikan orang lain, tidak suka menolong, selalu cuek, mementingkan diri sendiri, acuh tak acuh dan tidak memiliki inisiatif untuk membantu orang yang kesusahan sehingga bersifat negatif, penelitian menemukan16 siswa lainnya memiliki gejala-gejala seperti kepribadian yang baik dengan karakter membantu orang lain memiliki sifat sangat senang memberikan bantuan kepada teman yang mengalami kesusahan dalam mengerjakan tugas, memiliki rasa cemas jika melihat teman yang mengalami kesusahan dalam membaca, dan merasa senang ketika bisa membantu teman pada saat mengikuti perlombaan di sekolah.. Karakter ini disebut dengan self succorance.

\subsection{Self Succorance}

Self Succorance adalah kebutuhan untuk mendapatkan bantuan orang lain,meliputi dapat memberikan bantuan kepada orang lain apabila dalam keadaan susah,mencari dukungan dari orang lain,memiliki sifat simpati terhadap orang lain. MenurutDharsana,(2017). Dari definisi tersebut memiliki beberapa indicator yaitu: (1) Karakter untuk membantu orang lain. Menurut Dharsana, \& Suranata, (2014). (2) Karakter untuk memotivasi orang lain. Menurut Dharsana, (2017).(3) Karakter untuk menolong orang lain. Menurut Dharsana, (2014).

\subsection{Penerapan Self Succorance:}

Penerapan self succorance dapat dilakukan dengan cara atau teknik modeling. Siswa dapat melakukan penerapan teknik modeling dengan cara memperagakan simulasi pekerjaan yang sesuai dengan self succorance. Setelah itu siswa melakukan one stay two stray untuk mengetahui hasil diskusi dari kelompok lain. Setelah one stay two stray siswa melakukan sdrama yang telah dibuat dengan tema self succorance dan menampilkannya di depan kelas. Setelah melakukan drama penulis melakukan teknik placebo, dimana salah satu siswa akan disampaikan sikap positif dan negatifnya oleh 2 orang temannya. Dalam teknik placebo memiliki kode etik yaitu tidak boleh marah, dendam, dan tersinggung. Setelah melakukan teknik placebo siswa akan membacakan buku harian yang telah dibuat. Lalu siswa mengisi kuesioner yang telah dibagikan oleh penulis. Terakhir siswa mengisi jurnal refleksi tentang kegiatan layanan Bimbingan Klasikal yang telah dilakukan. 


\subsection{Teori Konseling Behavioral}

Konseling Behavioral mengandung filosofi yang memandang bahwa manusia memiliiki potensi untuk berperilaku baik atau buruk, tepat atau salah, manusia mampu malakukan refleksi atas tingkah lakunya sendiri, dapat mengatur serta mengontrol perilakunya dan dapat belajar tingkah laku baru atau dapat mempengaruhi perilaku orang lain. Ahli lain juga mengatakan konseling behavioral adalah upaya untuk membantu orang lain agar ia mampu tumbuh ke arah yang dipilihnya sendiri, mampu memecahkan masalah yang dihadapinya dan mampu menghadapi krisis-krisis yang dialami dalam kehidupannya. Yusuf \& Juntika, (2005:9).

\subsection{Teknik Modeling}

Teknik modeling adalah cara untuk cara untuk memperkenalkan dan konselor menyediakan model yang memiliki self-succorance tinggi untuk dapat melakukan hal itu, siswa diminta untuk meniru model yang telah disediakan oleh konselor. Modeling juga disebut peniruan (imitation), yaitu menunjukan bahwa perilaku orang lain yang diamati, ditiru, lebih merupakan peniruan terhadap apa yang dilihat dan diamati. Dharsana, (2015).

\section{Metode}

Jenis penelitian yang digunakan dalam penelitian ini adalah rancangan penelitian "eksperimen semu dengan pretest-postest control group design. Dalam pengambilan sampel, teknik yang digunakan random sampling. Adapun yang dimaksud dengan random sampling yaitu pengambilan sampel anggota populasi dilakukan dengan memilih sample secara acak, tanpa memperhatikan strata yang ada dalam populasi itu. Semua objek disuatu kelas tersebut dianggap memiliki kesempatan yang sama untuk diambi lsebagai sampel (Dantes, 2012). Penelitian ini mengambil jumlah sampel siswa yang menunjukkan criteria selfsuccorance sedang maupun rendah sebanyak 30 orang siswa.Untuk mengumpulkan data tentang self succorance siswa dan untuk memperoleh data yang akurat maka dalam penelitian ini menggunakan beberapa teknik pengumpulan data beserta masing-masing perangkat pengumpulan datanya yaitu: (1) Kuesioner, (2) Metode Observasi, (3) Metode Wawancara, (4) Buku Harian.

\section{Hasil dan Pembahasan}

Data yang digunakan dalam penelitian ini di dapatkan dari data hasil penyebaran kuisioner self succorance pada kelas eksperimen yaitu kelas VIII.4 dan kelas kontrol yaitu kelas VIII.9 dengan mengambil tahap pretes dan juga postes. Kemudian data pretes dan postes dari hasil kuisioner tersebut di analisis dengan uji-t untuk mencari perbedaan antara postes eksperimen dan postes kontrol. Proses perhitungan uji-t dalam penelitian ini menggunakan aplikasi JASP 10.0. Untuk mencari efektivitas dilanjutkan dengan menggunakan rumus effect size.

\section{Uji-t}

Untuk mengukur perbedaan antara data kelas kontrol dan kelas eksperimen dalam penelitian ini digunakan uji-t. Berdasarkan uji-t yang dilaksanakan peneliti didapatkan $t_{\text {hit }}$ sebesar 
14.921 dengan signifikansi $<0.05$ Uji $\mathrm{T}$ dilaksanakan dengan menggunakan perhitungan manual yaitu dengan menggunakan aplikasi JASP 0.10.0.0 Dengan rincian seperti yang diuraikan di bawah ini pada tabel 1 .

Tabel 1 Independent Samples T-Test

\begin{tabular}{lllllll}
\hline & & & & \multicolumn{3}{c}{$95 \%$ CI for Cohen's d } \\
& & & & & \\
\cline { 5 - 7 } & & Df & $\mathrm{p}$ & Cohen's d Lower & Upper \\
\hline $\mathrm{y} 1$ & -1.591 & 58.000 & 0.117 & -0.411 & -0.921 & 0.102 \\
$\mathrm{y} 2$ & 14.921 & 58.000 & 0.297 & 3.853 & 2.983 & 4.710 \\
\hline
\end{tabular}

Note. Student's t-test.

Berdasarkan tabel data analisis diatas tentang independent sampel t-test dapat diketahui bahwa nilai t untuk skor pretest yaitu $\mathrm{t}(58)=-1.591, \mathrm{p}<0,05$, dengan effect size pada D' Cohen $=-0.411$ yang dapat dimaknai bahwa tidak terdapat efektivitas konseling behavioral yang significant terhadap peningkatan self succorance dengan besaran efektivitas -0.411 atau pada kualitas rendah.

Sedangakan untuk posttes yaitu $\mathrm{t}(58)=14.921, \mathrm{p}<0,05$, dengan effect size pada $\mathrm{D}^{\prime}$ Cohen $=3.853$ yang dapat dimaknai bahwa terdapat efektivitas konseling behavioral yang significant terhadap peningkatan self succorance dengan besaran efektivitas 3.853 atau pada kualitas tinggi.

\section{Penutup}

Berdasarkan hasil analisis dan pembahasan pada bab sebelumnya dinyatakan bahwa hipotesis penelitian yang diajukan diterima berdasarkan taraf signifikansi $5 \%(0,05)$, dapat disimpulkan bahwa Hasil penelitian ini menunjukkan bahwa self succorance siswa yang mengikuti konseling behavioral mengunakan teknik modeling lebih meningkat dari pada siswa yang berada pada kelompok kontrol. Berdasarkan pernyataan ini dapat kita katakan bahwa konseling behavioral mengunakan teknik modeling efektif diterapkan di sekolah. Penerapan konseling behavioral mengunakan teknik modeling berimplikasi terhadap perencanaan dan pengembangan model layanan bimbingan konseling dalam hal teknik dan prosedur kegiatan layanan yang diberikan kepada konseli.

Dari hasil analisis penelitian, maka diperolehlah hasil yaitu ditemukan bahwa layanan bimbingan konseling akan lebih efektif jika konseli dalam pelaksananaan layanan difasilitasi dengan konseling behavioral mengunakan teknik modeling. 


\section{Daftar Pustaka}

Dantes, N. (2012). Effectiveness of Group Counseling To Increase Confidence Graders viii Smp Negeri 3 Singaraja in the academic year 2013/2014. Scientific Journal of Guidance and Counseling Undiksha, 2 (1).

Dharsana, IK (2013). Counseling Basics Series 2. Singaraja: Guidance and Counseling Department of the Faculty of Education University Pendidika Ganesha.

Dharsana, IK (2015). Counseling Cognitive Behavioral Modeling With The Figure Of Dharmawangsa To Increase Verbal, 1 (1). Https://Doi.Org/10.23887/128232017

Dharsana, IK (2017). Personal Development Counseling Through Superior Cognitive Modeling With Vasudeva Krishna And Glorious Bhisma, 1 (2), 119-127. Https://Doi.Org/10.23887/128222017

Dharsana, K. (2014). With Behavioral Counseling And Engineering Modeling Technique Token Economy To Improve Confidence Introduction, 1 (2), 77-85. Https://Doi.Org/10.23887/128182017

Dharsana, IK, \& Suranata, K. (2014). Application of Behavioral Counseling With Modeling Techniques To Minimize Aggressive Behavior Grade Language Xi Sma Negeri 2 Singaraja. Scientific Journal of Guidance and Counseling Undiksha, 2 (1). Retrieved From Http://Ejournal.Undiksha.Ac.Id/Index.Php/Jjbk/Article/View/3717

Djumhar and Moh.Surya. 1975. Guidance and Counseling in Schools (Guidance \& Counseling). Bandung: CV Sciences.

Gray, J. (2012). Gli uomini le donne Marte vengono da da Venere. Rizzoli. Retrieved from https://www.google.com/books?hl=en\&lr=\&id=Dnx-

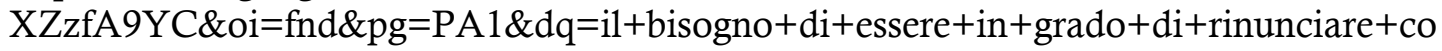
mprende+sentirsi + in + colpa + quando $s i+++$ errori commettono, + Ricevere + Torto + quando $\mathrm{si}+++\mathrm{fa}+$ qualcosa che è +++ non giusto, + più + per + ottenere + infelicit

John Wiley \& Sons, I. (1970). Theories of Personality (second). America.

Koyan, W. (2012). Education Statistics. singaraja: Ganesha Education University Press.

Mahmudi, A. (2009). Developing Teacher Competence Through Lesson Study. In the Journal of Guidance and Counseling Education Forum Unsri (Vol. 28).

Murray. (2010). Needs (Needs), 12-30.

Pietrofesa, John J, et al. 1978. Counseling: Theory, Research, and Practice, Chicago: Rand Mcnally College Publishing Company.

Prayitno and Erman Amti. 2004. Fundamentals of Guidance and Counseling. Second printing.

Sukmadinata. (2003). Runway Psychology Education Process. Bandung. PT Youth Rosdakarya.

Joseph \& Juntika. (2005). The cornerstone of Guidance and Counseling. Bandung. Rosda.

Supriatna, M. (Eds), 2011.Bimbingan and Competency-Based Counseling. Basic Orientation Counselors Professional Development. Jakarta: Rajawali Press. 
Article Information (Supplementary)

\section{Conflict of Interest Disclosures:}

The authors declare that they have no significant competing financial, professional or personal interests that might have influenced the performance or presentation of the work described in this manuscript.

Copyrights Holder: <authors $><$ year $>$

First Publication Right: BISMA The Journal of Counseling

https://doi.org/10.xxxx/ $\mathbf{x x x x x}$

Open Access Article | CC-BY Creative Commons Attribution 4.0 International License.

Word Count: 